\title{
DUTIES OF SAMARITANISM AND POLITICAL OBLIGATION
}

\author{
Massimo Renzo \\ University of Stirling Department of Philosophy
}

In this article I criticize a theory of political obligation recently put forward by Christopher Wellman. Wellman's "samaritan theory" grounds both state legitimacy and political obligation in a natural duty to help people in need when this can be done without unreasonable cost. I argue that this view is not able to account for some important features of the relation between state and citizens that Wellman himself seems to value. My conclusion is that the samaritan theory can be accepted only if we are ready to give up either the traditional notion of political obligation as a prima facie duty valid for every citizen or the current view of the relationships that should exist between states, citizens, and foreigners (the view according to which states should have special concerns for their own citizens).

Christopher Wellman has recently put forward a theory of political obligation based on the principle of samaritanism, ${ }^{1}$ that is, on a natural duty to help people in need when this can be done at "no unreasonable cost." 2

The theory looks promising, insofar as it seems able to avoid the two main problems faced by traditional consent-based and contract-based theories of political obligation while at the same time maintaining the intuition that made these theories so popular in the liberal tradition.

The intuition in question is the widely shared idea that the justification of political obligation has something to do with the benefits supplied by the state to its citizens. The problems are that since nobody has ever had the chance to ask for these benefits or to accept them, it is doubtful that we can derive from them a duty to obey the state. Furthermore, these theories can be charged with paternalism: we incur political obligation because of benefits that the state believes we need but that we might not be

1. Christopher H. Wellman, Samaritanism and the Duty to Obey the Law, in CHRISTOPHER H. Wellman \& A. John Simmons, Is There a Duty to Obey the LaW? 3 (2005).

2. Wellman understands natural duties in a weak sense: they are not dependent upon any previous transaction or preexisting association between the parts involved; $i d$. at 36. See John Rawls, A Theory of Justice-Revised Edition 98-101 (1999); A. John Simmons, Moral Principles and Political Obligation 13-14 (1979). 
interested in (at least not if the price to pay for them is obedience to the law).

I believe that the main appeal of the samaritan theory is its ability to avoid these two problems. Wellman's theory, while grounding political obligation in state benefits, focuses on benefits provided to other people rather than to ourselves: we have a duty to obey the state because this is the only way to save others from the perils of the state of nature. Since we do not expect that a person in danger has to accept our help explicitly before we aid her, we do not need to give any account of the acceptance conditions required for such aid being justified. Since the benefits in question are provided to others, state intervention cannot be rejected as paternalistic towards us.

My aim is to examine in detail Wellman's theory in order to show that while it is actually able to address these two problems, it is not able to account for some important features of the relation between state and citizens that Wellman himself seems to value. In particular, I argue that in order to accept the samaritan theory, we would have to give up either the traditional notion of political obligation as a prima facie duty valid for every citizen or the current view of the relationships that should exist between states, citizens, and foreigners (the view according to which states should have special concerns for their own citizens).

My discussion is in six sections. First I give a brief exposition of Wellman's theory (sec. I). Then I argue that the samaritan principle is not able to justify states' special redistributive responsibilities toward their own citizens (sect. II). In sections III and IV, I consider two possible kinds of reply to my objection and reject each of them in turn. In section V, I consider Wellman's suggestion that the samaritan theory could at least give us a justification for a minimal state, and I reject this possibility as well. Finally, in section VI, I consider some possible tensions existing between the two main principles adopted by Wellman in order to ground his theory of political obligation.

\section{WELLMAN'S THEORY}

Like most theories of political obligation, Wellman's account is made up of a descriptive part and a normative one. The former consists of three claims:

(1) States provide vitally important benefits;

(2) These benefits could not be secured in the absence of states;

(3) States can provide such benefits without imposing unreasonable costs upon their citizens. ${ }^{3}$

3. As Wellman himself acknowledges, the third claim is not wholly descriptive, for it includes the idea that no one could righteously refuse to pay these costs; Wellman, supra note 1, at 23. 
None of these claims has gone unchallenged in the debate about political obligation, ${ }^{4}$ but I will not say much about them because I agree to a great extent with the way they are defended by Wellman. ${ }^{5}$

The vitally important benefits in question are those produced by states performing their legislative, executive, and judicial functions. These kinds of benefit, according to Wellman, can be supplied only by an organization able uniformly to coerce everyone within its territorial boundaries. Private protection organizations would not be able to do that because they would not garner universal subscription. So they would lack "the authority to definitively establish a common set of rules, to effectively and uniformly enforce these rules, and to impartially adjudicate potential conflicts under these rules."

If anything, according to Wellman, private organizations are likely to magnify these conflicts, because the very logic of this kind of organization is to protect its own clients rather than to ensure a just resolution of conflicts. For this reason they would do nothing but reproduce on a larger scale the conflicts between their clients. ${ }^{7}$

Claim 3 is probably the most controversial of the three. Wellman admits that states demand from their citizens substantial sacrifices, but he claims that once we consider the great benefits that citizens receive, it will be clear that the costs that states impose upon them are not unreasonably great. ${ }^{8}$

The normative part of Wellman's account consists of two principles: the samaritan principle and the principle of fairness. He needs them both because his justification of political obligation is in two stages: first he gives a justification of state legitimacy, that is, of why it is permissible for states to coerce their citizens; then he gives a justification of political obligation in its strictest sense, that is, of citizens' duty to comply with the laws of the state. ${ }^{9}$

4. Claim 2 in particular has been put in question by those who believe that in the absence of states all their main functions could be provided by private enterprises. See DAvid Friedman, The Machinery of Freedom (1973); John Sneed, Order without Law: Where Will Anarchists Keep the Madmen? 1 J. Libertarian STud. 117-124 (1977); Bruce Benson, The ENTERPRISE OF LaW (1990); RANDY BarnetT, The STRUCTURE OF LiberTy (2000).

5. Wellman, supra note 1 , at 5-17.

6. Id. at 16 .

7. The same point is made by Jeremy Waldron, Special Ties and Natural Duties, 22 PHIL. \& Pub. AfF. 22-23 (1993).

8. For a criticism of this claim, see George Klosko, Samaritanism and Political Obligation: A Response to Christopher Wellman's "Liberal Theory of Political Obligation," 113 EтHICs 835-840 (2003); A. John Simmons, The Duty to Obey and Our Natural Moral Duties, in Christopher H. Wellman \& A. John Simmons, Is There a Duty to Obey the LaW? (2005), at 181-182.

9. Wellman subscribes to the view that state legitimacy and the duty to obey the state are not Hohfeldian correlates. For he believes that a state's right to coerce its citizens correlates to citizens' lack of right not to be coerced by it rather than to citizens' moral duty to obey it; see Christopher H. Wellman, Toward a Liberal Theory of Political Obligation, 111 ETHICs 741-742 (2001). This distinction is earlier stressed by Robert Ladenson, In Defense of a Hobbesian Conception of Law, 9 Phil. \& Pub. Aff. 134-159 (1980); Rolf Sartorius, Political Authority and Political Obligation, 67 Va. L. Rev. 3-17 (1981); Leslie Green, The Authority of the State (1988); Kent Greenawalt, Conflicts of LaW and Morality (1989). See also William A. Edmundson, Three Anarchical Fallacies: An Essay On Political Authority (1998). 
The samaritan principle by itself is sufficient to justify the former but not the latter.

Consider the problem of state legitimacy first. According to the samaritan principle, we are morally permitted to do what is necessary to rescue someone from serious peril if in doing so we do not impose unreasonable costs on others. Even if the principle has been rejected by some,${ }^{10} \mathrm{I}$ think that it is not particularly controversial, as we can see in Wellman's example: suppose that Amy has a seizure and can be saved only if Beth takes her immediately to the nearest hospital. Suppose also that the only car in the vicinity is Cathy's car, but Cathy is not around. Is Beth justified in commandeering Cathy's car to drive Amy to the hospital? Given the extreme circumstances, most of us would probably admit that she is. "[T] he fact that Amy's life hangs in the balance gives Beth's mission an urgency that outweighs Cathy's normally decisive dominion over her self-regarding affairs." 11

According to Wellman, a "state's nonconsensual coercion of its citizens is morally analogous to Beth's nonconsensual borrowing of Cathy's car insofar as each is necessary 'to prevent extremely unhappy occurrences." 12 States are ultimately permitted to coerce me because this is the only way to save my compatriots from the perils of a lawless environment and this coercion is not unreasonably costly to me.

This is the reason why it is so important for Wellman's theory that both claims 2 and 3 are fulfilled. If it were possible to take Amy to the hospital in some other way (e.g., by taxi), it would not be permissible for Beth to commandeer Cathy's car. And if saving Amy would require some more costly action (e.g., chopping off one of Cathy's arms), Beth would not be permitted to do it, even if this were the only way to save Amy. For the same reasons, if the state's existence were not the only way to save my compatriots from the perils of a lawless environment or if the state could accomplish this only by imposing an unreasonable cost upon me, it would not be permitted to coerce me. ${ }^{13}$

So far the samaritan principle has been used by Wellman in order to justify state legitimacy. But since without citizens' compliance states would not be able to perform those functions that are required to eliminate the

10. See, e.g., Jeffrie G. Murphy, Blackmail: A Preliminary Inquiry, 63 Monist 168 n.6 (1980). A good discussion of the samaritan principle can be found in Jokl FeInberg, Harm to Others 126-186 (1984), but notice that Feinberg's interpretation of the principle is different from the one offered by Wellman. According to Feinberg, samaritan duties issue from his "harm principle," whereas according to Wellman, they issue from a different "benefit to others" principle; see Christopher H. Wellman, Liberalism, Samaritanism, and Political Legitimacy, 25 Phil. \& Pub. Aff. 224-229 (1996).

11. Wellman, supra note 1 , at 21.

12. Id. at 22. It is it worth noting that the adjective "nonconsensual" can have two different meanings. It can mean either "without consent" or "despite dissent." Cathy does not consent to have her car taken by Beth, but she does not dissent either, whereas some of the citizens coerced by the state do dissent. However, this is not to be considered an objection to Wellman, for I certainly agree that Beth would be justified in taking Cathy's car even if Cathy dissented.

13. Wellman, supra note 1, at 22-23. 
perils of the state of nature, it is clear that the samaritan principle plays a major role also in justifying the duty to obey the state.

If perils for others can explain why I may possibly be coerced to help them, they can also explain why I have an obligation to assist others if it is not unreasonable costly. This is confirmed once again by Beth's example: most of us would admit not only that Beth may permissibly commandeer Cathy's car but also that Cathy has a moral duty to lend her car in that particular situation. For the same reasons, those very perils for our compatriots that justify the legitimacy of state coercion also justify our duty to support the action of the state by obeying its laws:

[G]iven that states rescue us all from the perilous circumstances that would inevitably prevail in their absence, and because states rely upon the compliance of their constituents to perform their political functions, it seems to follow that each of us has a samaritan duty to obey the law. ${ }^{14}$

Hence the samaritan principle clearly has both a "permissive part" and a "requiring part." ${ }^{15}$ The former is meant to explain why we can legitimately be coerced by the state in order to rescue others from the perils of the state of nature (when such coercion is not unreasonably costly). The latter states that we have a natural moral duty to rescue those who are in serious danger (if this is not unreasonably costly for us), and is meant to answer the question of political obligation in its strictest sense (i.e., of the duty to obey the state). ${ }^{16}$

Now, the problem is that while the permissive part of the principle is sufficient to justify state legitimacy, the requiring part is not sufficient to justify political obligation. First, even if we grant that the only way to discharge our samaritan duty is by supporting and complying with our own states, we should notice that what is necessary to ensure the state's existence is collective obedience to the law rather than obedience by every particular individual. For it is clearly false that if I did not obey the laws of my state, we would return to the perilous circumstances of the state of nature. Whether I obey or disobey the law typically makes no difference to the existence of the state and hence to its capacity to rescue others from the perils of the state of nature.

This is the reason why, in order to ground a duty to obey the law for each citizen, the samaritan principle needs to be supplemented by the principle of fairness. ${ }^{17}$ Since states are nothing more than the "coerced coordination"

14. Id. at 31 .

15. I borrow these labels from Simmons, supra note 8, at 180 .

16. As already noted, in the current debate both the question of state coercion and the question of citizens' duty to obey the state are often mixed under the heading of "political obligation." In this article I reserve this expression for the second problem, while I use the expression "state legitimacy" to indicate the first.

17. Wellman's theory, then, like the one recently proposed by George Klosko, is a "multiple principle" or "mixed" theory of political obligation. See George Klosko, Political Obligations (2005); Jonathan Wolff, Political Obligation: A Pluralistic Approach, in PluRAlism: The Philosophy 
of individuals composing them, ${ }^{18}$ and the fewer individuals who comply with state demands the more burdensome these demands will be, Wellman argues that fairness requires that everyone should do their part in supporting the state's action by obeying its laws. ${ }^{19}$

However, it is controversial in the first place that the only way to discharge our samaritan duties is actually by obeying our own states, and Wellman's argument so far does not suffice to show that this is the case. Samaritan duties, like all natural duties, hold for persons generally, as opposed to specific groups. So the question is: Why should we fulfill our natural duty to aid others generally by obeying the law of our own state? It seems that we might fulfill our natural duty to help others as well by supporting:

nonpolitical rather than political institutions (e.g., Oxfam or other famine-relief organizations);

political institutions of other countries;

political institutions of our country but in some way other than by obeying its laws.

In fact, once we adopt the samaritan theory, these seem to be something more than mere possibilities. Given that, for example, people living in the Third World are usually in more serious need than needy Italians, it seems that I should be required by the samaritan principle to withhold my taxes and send the equivalent amount of money to some of the poorest states in the Third World or maybe to famine-relief associations operating in those areas.

Wellman's theory, like all theories of political obligation based on natural duties, seems to encounter problems in accounting for what John Simmons famously called the "particularity requirement," that is, in accounting for the fact that we must discharge our natural duty by supporting and complying with our own state in particular. ${ }^{20}$

Wellman's answer to this problem is that the only way to eliminate the kind of instability which is characteristic of lawless environments is through the action of territorially defined states. But none of these states would be able to perform its functions if it were not able to coerce everyone living

AND Politics of Diversity 179 (Maria Baghramian and Attracta Ingram eds., 2000); William A Edmundson, State of the Art: The Duty to Obey the Law, 10 Legal TheOry 249-252 (2004).

18. Wellman, supra note 1 , at 33 .

19. This conclusion might be rejected by those who defend a voluntarist account of the principle of fair play, according to which we can have a duty under the principle of fair play only if we first accept being participants in the cooperative scheme; see A. John Simmons, The Principle of Fair Play, 8 PHIL. \& Pub. AfF. 307-337 (1979); and A. John Simmons, Fair Play and Political Obligation: Twenty Years Later, in JustificATION AND Legitimacy: EssaYs ON Rights AND OBLIGATIONS 27 (2001). I personally believe that this is how the principle should be understood, but for the sake of argument, in the rest of my article I grant Wellman's nonvoluntarist interpretation of the principle.

20. John Simmons was the first to formulate this requirement; see Simmons, supra note 2, at 30-35. See also Christopher H. Wellman, Political Obligation and the Particularity Requirement, 10 LEGAL THEORY 97-115 (2004). 
within its boundaries. This is the reason why I (as well as those living in the same territory where I live) should support my state by obeying its laws rather than adopt any of the three mentioned alternatives:

The point ... is that the perils that prevail in the absence of political society are distinct insofar as they create what is fundamentally a coordination problem: there is no way other than general compliance with a single authoritative set of rules to secure peace and protect basic moral rights. ${ }^{21}$

Again, the fact that "general compliance" is required in order to solve the coordination problem does not entail that "each of us" has a duty to comply with the laws of our state. Even if states are justified in coercing their constituents because this is the only way to eliminate perils caused by political instability, obedience by every particular individual is still not necessary to achieve this result. If I stopped obeying my state and started to discharge my samaritan duties by supporting some other state or institution, this would not affect the capacity of my state to solve the coordination problem.

However, I would be able to enjoy this discretion only because enough of my fellow citizens kept on obeying the laws of my state. If everyone were given the option of deciding how to discharge her own samaritan duties, the state would not be able to solve the coordination problem. So once again the samaritan account needs to be supplemented by the principle of fairness: since my enjoying such a discretion depends upon the denial of the same discretion to others, I could enjoy it only by free-riding on other citizens' obedience. But fairness clearly prohibits this kind of behavior; hence Wellman can conclude that no one is free to enjoy such a discretion: ${ }^{22}$

Thus, even though the samaritan account of our duty to obey the law begins with a natural duty, it can satisfy the particularity requirement because there is a straightforward explanation for why our duty to do our fair share to rescue others from peril must come in the particular form of obedience to the laws of one's own state. ${ }^{23}$

\section{AN OBJECTION TO WELLMAN}

Let us grant for now that Wellman is successful in showing why his theory requires us to fulfil our samaritan duty by obeying the laws of our own state

21. Wellman, supra note 1 , at 45 .

22. Wellman, supra note 20, at 109-111. Notice, however, that exercising this kind of discretion would not be unfair if it were possible to distribute the right to do so by some fair procedure (e.g., a lottery). Since Wellman seems to agree that a limited amount of discretion would not affect the state's ability to perform its functions, he should probably consider the possibility of granting the right to decide how to discharge our samaritan duty to a limited number of individuals, to be selected according to a fair procedure.

23. Wellman, supra note 1 , at 46 . 
rather than in any other possible way. I agree that this would be enough to account for the particularity requirement as it has been formulated by Simmons. But I think that an adequate formulation of this requirement should lead us to pay attention not only to that bond that ties us especially to our state (as in Simmons's formulation) ${ }^{24}$ but also to that bond that ties our state especially to us.

I think that Wellman's theory can account for the former but not for the latter. The reason it is unable to do this is that the state's nonconsensual coercion of its citizens is not "morally analogous" to Beth's nonconsensual borrowing of Cathy's car. And the reason the two things are not morally analogous is that while Beth's action can actually be grounded in a natural duty to aid others, the state's coercion cannot.

To see what I mean, let us start by considering Beth's example in a slightly modified version. Suppose that both Amy and Diana have a seizure and need to be taken by Beth to the nearest hospital. Suppose that Cathy's car is really small and can carry only one passenger beside the driver. Suppose that Beth is a doctor and realizes that Diana is in worse condition than Amy. Of course, in the case of Amy, too, "the sooner the better," ${ }^{25}$ but she will survive anyway; while Diana, if not taken immediately to the hospital, is certainly going to die.

I think that in this case the samaritan duty requires Beth to take Diana to the hospital rather than Amy. For, all things being equal, we have a stronger samaritan duty to help $\mathrm{X}$ rather than $\mathrm{Y}$ if $\mathrm{X}$ is in a worse situation than $\mathrm{Y}^{26}$ (provided that Y's condition is over a certain threshold). Now, if the state's coercion of its citizens were justified by the same kind of duty, we should expect our states to give precedence in their actions of helping the needy to those in worse condition (provided that the situation of the needy in "better condition" is over a certain threshold). ${ }^{27}$ But this is not what we actually expect from them. What we expect is that each state will pay special attention to its own citizens.

For example, we take it for granted that Italy should pay more attention to those of the needy who are Italian (Italian needy), even if as a matter of

\footnotetext{
24. Simmons, supra note 2 , at $31,34,155$; Simmons, supra note 8 , at 110,166 . See also Wellman, supra note 20 , at 98 .

25. Suppose that if Amy is taken too late to the hospital, she is going to suffer some kind of permanent injury (say, lose one of her arms).

26. Assuming, for example, that $\mathrm{X}$ and $\mathrm{Y}$ are both nonresponsible (or equally responsible) for their being in danger and that the likelihood of a successful rescue is the same in either case.

27. For example, provided that basic needs of the needy in better condition are met. I do not mention this clause every time I consider my objection in the text, but it is essential for my argument to work. If the dangers of both those in "worse" and those in "better" conditions are under a certain threshold, the samaritan principle will not necessarily require us to save those in worse condition. Suppose that citizens of state One are at serious risk of dying of starvation, while citizens of state Two are at the same risk of dying of starvation but are also at risk of dying of diseases. I would say that the latter are in worse condition, but I do not think that the samaritan principle would require us to save them rather than the former if the risk run by the former is quite high.
} 
fact most of them are in much less parlous condition than the needy in the Third World. But if we really believed that state legitimacy were grounded in a natural duty to help others, then we should believe that Italy ought to be equally concerned about helping both Italian needy and the needy living in the Third World and hence believe that Italy ought to help those among them who are in more danger.

Wellman is certainly right in pointing out that most of the perils that our states are meant to save us from are those of lawlessness and lack of coordination. These problems can be resolved only through a coercive imposition of an authoritative set of rules, and obviously Italy lacks the authority to impose such a set of rules in the Third World; therefore Italy cannot rescue people living in the Third World from these kinds of peril. But not all the perils afflicting the needy in the Third World are of this nature. At least some of these perils are due not to lack of coordination but to famine or diseases. Thus, if state legitimacy were really justified by the principle of samaritanism (that is by a natural moral duty, owed by all individuals to all individuals, to perform easy rescues of those in serious peril), we should expect Italy to pay the same attention in its redistributive policies to Italians and to the needy in the Third World.

It is important not to misunderstand the focus of my objection. My objection here is not that the samaritan theory should require Italians to support some state in the Third World rather than Italy. Since, according to Wellman, the coordination problem can be solved only locally through the action of territorially defined states, and states could not perform their functions if they were not able to coerce everyone living within their boundaries, the samaritan theory cannot require Italians to withdraw their support from Italy, because this would put Italians back into the state of nature. ${ }^{28}$

My objection here is rather about what Italy should do once its existence is ensured by Italian citizens' support. Italy's capacity to rescue people from the perils of a lawless environment is necessarily limited to those living within its territory, but its capacity to rescue people from famine and disease is not limited in the same way. In principle it is not limited in any way, and the samaritan theory is not able to put any constraint on possible beneficiaries of Italian redistributive policies. So there seems to be no reason for Italy to pay special attention to the Italian needy with regard to such policies.

I think that Wellman's theory is able to answer the particularity objection as it is formulated by Simmons because it is plausible to maintain that the best way for Italy to rescue people generally (as opposed to people belonging to specific groups) from the perils of lawlessness and lack of coordination is to ensure stability within its boundaries. And hence it is plausible to claim that the best thing that Italians can do in order to rescue others generally from these kinds of danger is to obey their own state. 
What seems highly implausible is to claim that the best way for Italy to rescue people generally from problems due to lack of resources is to limit its redistributive policies just to its own citizens. This seems not to be the case, since most Italian needy, while facing a life of hardship and privation, are in a clearly less dangerous situation than those starving and dying every day of diseases in the Third World. And clearly the conditions of the needy in the Third World would be far better if states like Italy paid them the same attention that they currently pay their own citizens. Still, there seems to be nothing strange in claiming that each state should care especially about its own citizens. This is what states are usually supposed to do.

In order to have a clearer picture of this point, let us once again rewrite Wellman's example. Suppose that both Amy and Diana have a seizure and need to be taken to the nearest hospital. Suppose that Cathy's car can carry only one passenger. Suppose that Beth is a doctor and realizes that Diana is in worse condition than Amy, but Amy is Beth's daughter. Beth has no doubts and takes Amy rather than Diana to the hospital.

Usually states act like Beth does in this third version of the example. Moreover, we commonly believe that they are perfectly justified in acting like this, as we probably believe that Beth is justified in acting as she does. But clearly Beth here is not acting out of a natural duty to aid others but rather out of a duty deriving from a special relation. The problem that an adequate theory of political obligation should solve is precisely to specify the nature of this special relation. ${ }^{29}$

Probably Italy should spend more than it currently does for the needy in the Third World; still, most of us would find it odd to claim that Italy should pay exactly the same attention (e.g., by spending the same amount of money) to them and to the Italian needy. An adequate theory of state legitimacy and political obligation should account for this or alternatively explicitly reject this assumption, which seems to be widely shared.

That very bond that ties us especially to our state also ties our state especially to us, but the principle of samaritanism cannot account for that. As I will make clear, this is the reason why the principle is able to ground neither state legitimacy nor political obligation as we normally understand them.

\footnotetext{
29. I am not suggesting here that the nature of the special relationship between state and citizens is analogous to the relationship between Beth and her daughter. Such a view is defended by Ronald Dworkin, John Horton, and Michael Hardimon; see RonALD DwORKIN, LAW's Empire 186-216 (1986); John Horton, Political Obligation (1992); John Horton, In Defence of Associative Political Obligations: Part One, 54 Pol. STud. 427-443 (2006); John Horton, In Defence of Associative Political Obligations: Part Two, 55 Pol. STud. 1-19 (2007); Michael Hardimon, Role Obligations, 91 J. PHIL. 333-363 (1994). For problems with this approach, see A. John Simmons, Associative Political Obligations, 106 ETHICs 247-273 (1996); and A. John Simmons, External Justifications and Institutional Roles, 93 J. PHIL. 28-36 (1996), both reprinted in Simmons, Justification and Legitimacy: Essays on Rights and Obligations (2001). See also Christopher H. Wellman, Associative Allegiances and Political Obligations, 23 Soc. Theory \& Prac. 181-204 (1997).
} 


\section{FIRST REPLY BY WELLMAN}

Recall the core of my objection to Wellman thus for: the samaritan theory might be able to offer a justification for the fact that Italy is legitimated in coercing Italians as well as the fact that Italians should obey Italian laws and support Italy (rather than any other state). But it is not able to account for the fact that in its redistributive policies Italy should be more concerned about the Italian needy than about the needy in the Third World.

In some of his articles Wellman mentions, without discussing it in detail, this kind of problem. In this section and in the next one I consider and try to reject two strategies that he believes are sufficient to answer my objection.

First he argues that " $\mathrm{t}]$ he samaritan model does recognize an important difference between compatriots and foreigners . . . because the former contribute to one's own political benefits whereas the foreigners do not." ${ }^{30}$

Remember that the samaritan duty is a duty of easy rescue: we have a duty to help people in need only if we can do this without unreasonable cost. Now, in supporting our state, we help our compatriots but we also receive the great benefits of political stability. ${ }^{31}$ So it is less costly for us to help our fellow citizens than to help foreigners, because "the reasonableness of the chores we must perform is measured in terms of the burdens we endure minus the benefits we receive." ${ }^{32}$

I think this argument is unconvincing. Italy, like any other state, supplies two main sorts of benefits to its citizens: those connected with political stability (security, order, etc.) and those connected with redistributive policies. While all Italian citizens benefit from political stability, redistributive policies are meant to benefit only (or at least mostly) the Italian needy once political security is ensured. But once political stability is ensured, Italian contributors who are not in need do not get any relevant benefits from the fact that Italy's redistributive resources are employed to help Italian rather than foreign needy.

In what sense, according to Wellman, would limiting these policies to the Italian needy contribute to all Italians' benefit? Once Italy is supported by its citizens and is able to provide them with that political stability which makes the cost of such support not unreasonable, there seems to be nothing that Italian citizens would gain just from the fact that Italy's redistributive resources are limited to the Italian needy. And so there is no reason available within the samaritan theory to conclude that Italy should give precedence to the Italian needy if the needy in the Third World are in worse condition (and if the conditions of the Italian needy are over a certain threshold). ${ }^{33}$

30. Wellman, supra note 10, at 233 n.28.

31. Wellman, supra note 1 , at 17, 32. See also id. at 236; and Wellman, supra note 20, at 108 n.15.

32. Wellman, supra note 10 , at 233 n.28.

33. It is important to notice that if the conditions of the Italian needy were under the threshold below which differences in need are no longer relevant (see supra note 27), this 
Wellman's error is in counting the benefits of political stability twice, making them depend in part on employing redistributive resources to help the Italian needy. True, if the conditions of the Italian needy were bad enough, then not including them among the beneficiaries of Italian redistributive policies might endanger political stability. But this is not the case considered in my objection. Italy should certainly devote to the Italian needy all the resources that are necessary to ensure political stability. The problem at stake is, rather, how to employ those redistributive resources that are available once that political stability is ensured.

It is clearly not true that the only way for Italy to maintain political stability is to devote all (or almost all) of its redistributive resources to the Italian needy. Still, we believe that Italy should give precedence to its citizens, even if failing to do so would not endanger its political stability. So the point raised by my objection is not whether Italians should pay a higher price to support the needy in the Third World rather than the Italian needy, but rather whether (once political stability is not in doubt) the Italian needy have any special claim to Italian redistributive resources.

Italy has these resources thanks to Italian contributors, but however Italy spends them, this will not affect Italian contributors, since they were ready to pay that cost in order to discharge their samaritan duty. ${ }^{34}$ For these reasons I think we can conclude, contra Wellman, that helping foreigners is not necessarily more costly than helping compatriots. I try below to strengthen my case by arguing that my objection holds even if helping foreigners were more costly, provided that it is not too costly.

The first thing to notice here is that the existence of a samaritan duty for $\mathrm{X}$ to save $\mathrm{Y}$ depends on two conditions:

(1) Y must be in danger;

(2) X can save $\mathrm{Y}$ without unreasonable cost. ${ }^{35}$

Both conditions need to be satisfied in order to have a samaritan duty; but what happens when more than one person is a possible beneficiary

would just mean that they have a claim to Italian redistributive resources equal to the needy in the Third World, not a special claim.

34. A possible reply to this is to say that Italian resources might not be enough to help all the needy in the Third World whereas they could be enough to save all the Italian needy. But once again this objection would be misleading: the samaritan principle does not require saving all the persons in danger but just performing easy rescues. So if saving more than, say, one tenth of the needy in the Third World would be too costly for Italy, this would fall outside the samaritan duty. In that case, Italy's resources should be employed to save only one tenth of the needy in the Third World. Suppose now that the same resources would be enough to help all the Italian needy; why should the resources be employed to save them rather than one tenth of the needy in the Third World? Once we adopt the samaritan theory, it is not relevant to consider which state the needy belong to. My objection is that once we adopt the samaritan theory, Italy (and like Italy, all other states) should employ its redistributive resources to support the needy who are in the worst condition all over the world.

35. Wellman, supra note 10, at 215. 
of someone's samaritan duty? It seems that the only way to choose which person to help is to consider how dangerous their respective situations are and how costly helping each of them would be.

Suppose that X can save either $\mathrm{Y}$ or $\mathrm{Z}$ (and they are both perfect strangers to her). The cost involved in saving them is the same, but $Y$ is in more serious danger than Z. Clearly, in this case $\mathrm{X}$ should save $\mathrm{Y} .{ }^{36}$ Suppose now that $\mathrm{Y}$ and $\mathrm{Z}$ are in the same kind of danger, but for $\mathrm{X}$ it would be more costly to save $Y$ (even if in neither case would the cost be unreasonable). Probably here it would not be quite right to say that $\mathrm{X}$ has a "stronger" duty to save $\mathrm{Z}$; still, we would probably agree that if $\mathrm{X}$ were ready to save $\mathrm{Z}$, asking her to save $\mathrm{Y}$ rather than $\mathrm{Z}$ would be to ask $\mathrm{X}$ to do "something more" than her strict duty. Furthermore, if X saved neither of them, she would probably be more condemnable for failing to save $\mathrm{Z}$ than for failing to save $\mathrm{Y}$.

In these two cases it seems to be clear enough what X should do. It becomes more difficult to decide what she should do when neither the dangers for $\mathrm{Y}$ and $\mathrm{Z}$ nor the costs involved in saving them are exactly the same. In such cases it seems reasonable to say that $X$ should take into account the trade-off between the perils of Y's and Z's respective situations and the costs of saving them. So if $Y$ is in a much more dangerous situation than $\mathrm{Z}, \mathrm{X}$ will probably have a stronger duty to save $\mathrm{Y}$ even if it would be slightly more costly than to save Z. ${ }^{37}$

Now, if this is how the samaritan principle should be applied, and if Italians' duty to support their state were rooted in such a principle, it would not be unrealistic to claim that Italy should be more concerned about the needy in the Third World rather than about Italian ones, even if supporting those in the Third World were more costly (provided that it were not too costly to count as a samaritan duty). ${ }^{38}$

36. This is the case described in my reformulation of Wellman's example about Beth in section II.

37. For the same reason, we can conclude that if saving $\mathrm{Y}$ would be much more costly than saving $\mathrm{Z}, \mathrm{X}$ might have more reasons to save $\mathrm{Z}$ rather than $\mathrm{Y}$, even if $\mathrm{Y}$ is in a slightly more dangerous situation. But notice that someone might disagree about that. It might be argued that since, ex hypothesi, both the cost of saving $\mathrm{Y}$ and the cost of saving $\mathrm{Z}$ are not unreasonable, $\mathrm{X}$ has a stronger duty to save $\mathrm{Y}$ because $\mathrm{Y}$ is in a more dangerous (even if only slightly more dangerous) situation. The fact that saving $\mathrm{Y}$ would be much more costly might be considered irrelevant here because we are assuming that the cost is not unreasonable anyway. Adopting this position would make my argument even stronger, though, for it would lead us to conclude that Italy should support the needy elsewhere, rather than Italians, not only when this produces a better trade-off between dangers and costs but also when the trade-off is worse than in helping Italians and the conditions of the non-Italian needy are not much worse than the conditions of the Italian needy.

38. But notice that according to my objection, helping them is never going to be too costly. As already pointed out (supra note 34 ), what is put in question by my objection is not whether Italians should pay a higher price to support the needy in the Third World rather than the Italian needy but whether redistributive resources that Italy has at its disposal should be devoted to the Third World rather than to Italians. 


\section{SECOND REPLY BY WELLMAN}

Another way in which Wellman tries to deal with the objection that I am considering is by supplementing his theory with three further considerations that, according to him, will allow the samaritan theory to account for states' special redistributive responsibilities toward their own citizens:

Because samaritan responsibilities are owed equally toward all humans (as opposed to merely toward compatriots), it appears that any account based on samaritan duties could not explain these additional commitments [i.e., our special commitment to our own country and compatriots] and hence would not be able fully to match our understanding of our political obligations.

It strikes me that there is some truth to this objection: It is admittedly not clear how samaritanism could accommodate these intuitions. But even if samaritanism alone cannot account for all of our political responsibilities, there is no reason why it could not be combined with other considerations that do explain them. The basic idea here is that once samaritan-justified states are in place, their existence may change the moral landscape; there may be morally relevant features of the relationships among compatriots or between citizens and their states that in turn explain our additional political obligations. $^{39}$

In particular, Wellman argues that it is possible to justify our special commitment to our compatriots-and hence our more robust redistributive responsibilities to them-by considering:

(1) The importance of effective (as opposed to formal) rights;

(2) The importance of relational equality;

(3) The social nature of consumption. ${ }^{40}$

I will now examine these considerations in turn.

\section{A. Formal Rights versus Effective Rights}

Wellman points out that if excessive inequalities were allowed to exist between fellow citizens, the rights of those citizens who are poor would be rendered ineffective. He takes as an example the right to run for the Senate. Such a right, Wellman argues, is merely formal if I am a sharecropper competing against someone who owns newspapers and TV stations:

39. Wellman, supra note 20, at 111-112. See also Wellman, supra note 1, at 54-55, 72; Wellman, supra note 9, at 758-759; Wellman, supra note 10, at 237.

40. Christopher H. Wellman, Relational Facts in Liberal Political Theory: Is There Magic in the Pronoun "My"? 110 ETHICs 545-549 (2000). 
Gross economic disparities among the X-ians would typically pervert the political culture in X-land (by making wealthy X-ians disproportionately powerful and leaving poorer X-ians politically alienated and apathetic), but similar inequalities between X-ians and Y-landers need not corrupt Y-land's political processes. As a consequence, liberals have reason to be more vigilant to inequalities among $\mathrm{X}$-ians than inequalities between $\mathrm{X}$-ians and Y-landers because the former undermine the effectiveness of important rights in X-land in a way that the latter do not in Y-land. ${ }^{41}$

I am not sure that anyone who endorses a samaritan theory of political obligation can accept this conclusion, even while agreeing with Wellman about the risks of rights becoming ineffective.

Remember that according to Wellman's theory, states are legitimate insofar as they are instruments that allow citizens to discharge their samaritan duty. This means that if my state coerces me without allowing me to discharge such a duty, it is illegitimate, and I might be justified in withdrawing my support from it. On these premises, if Wellman agrees that in not being able to run for the Senate, I am in less danger than those starving in the Third World, he should also agree that my state is legitimate only if it devotes its resources to helping the Third World rather than to ensuring that I am not too poor to run for the Senate.

Of course, having my right to run for the Senate rendered ineffective could be considered a danger capable of triggering a samaritan duty, but as I point out above in my discussion of Amy's and Diana's seizures, samaritanism requires us to help $\mathrm{X}$ rather than $\mathrm{Y}$ if $\mathrm{X}$ is in a worse situation than $\mathrm{Y}$ (provided that Y's bad situation is under a certain threshold). So if Wellman believes that those starving in the Third World are more in danger but that nonetheless the legitimacy of my state does not depend on the state employing its resources to help them, it is because Wellman roots state legitimacy in something different from the samaritan principle (e.g., in the protection of certain basic democratic rights). ${ }^{42}$

At this point, Wellman could recall his first objection and reply that if the cost of helping the needy in the Third World were to render my right to run for the Senate ineffective, then the samaritan principle could not ask me to do that because it would be too costly to count as a samaritan duty. Also, he could argue that if I had my right to run for the Senate rendered ineffective my condition would fall under the threshold below which differences in need are no longer relevant. For these reasons, a state that would employ its redistributive resources to help the Third World rather than to render effective my right to run for the Senate would be illegitimate and I would not have any duty to obey it.

Now, I certainly agree that any well-functioning state should provide equality of access to political power for all of its citizens, and I also agree

41. Id. at 546 .

42. The right to run for the Senate would be one of these rights. 
that rendering my right to run for the Senate ineffective would be a price too high to be required by the samaritan principle. But states could ensure the effectiveness of such a right by setting some constraints on the amount of money and resources that any candidate is allowed to spend to finance her run for whichever public office rather than by reducing the economic inequalities between all citizens. These kinds of constraints on funds that can be used to finance electoral campaigns could hardly be considered an "unreasonable cost" and would permit the employment of most of the redistributive resources of my state to help the Third World while ensuring an effective right to run for the Senate for every citizen. ${ }^{43}$

\section{B. Relational Equality}

Wellman points out that:

the extent to which we should worry about inequality depends upon the nature of the relationship between the unequals. The inequality between the "haves" and the "have-nots" is much less worrisome if the two groups live in separate societies and have never heard of one another, for instance, than if the two coexist together in the same society. ${ }^{44}$

Wellman is here adopting a particular conception of "democratic equality" that has been defended by Elizabeth Anderson. ${ }^{45}$ The idea is that our concern for equality should not be limited to the distribution of goods but should take into account the relationship existing between people who share these goods. The aim is to eliminate "those inequalities which create socially oppressive relationships, ${ }^{" 66}$ but it is important to recognize that not all inequalities are of this kind: "the very same inequalities which might be morally problematic between a husband and a wife, for instance, may be benign when present between strangers." 47

According to Wellman:

It requires little imagination to see how this view of equality can help... explain why we might be required to transfer more to our compatriots. Very simply, insofar as citizens share an important relationship, inequalities between them may be especially problematic. Of course, I do not mean to deny that there may be significant relationships between foreigners; rather, I assert only that, ceteris paribus, the same inequalities which are worrisome

43. This way to guarantee equality of access to political power is also less intrusive and easier to bring about than reducing economic inequalities between citizens. I think that even some libertarians, while rejecting the latter, could accept the former.

44. Wellman, supra note 40 , at 546.

45. Elizabeth Anderson, What Is the Point of Equality? 109 ETHICs 287-337 (1999).

46. Wellman, supra note 40 , at 547.

47. Id. 
when present between compatriots need not be problematic between people who share no common state. ${ }^{48}$

My suspicion is that here Wellman is begging the question. It is true that "insofar as citizens share an important relationship, inequalities between them may be especially problematic," but the problem is precisely to give an account of what justifies the existence of this "important relationship." According to Wellman's theory, the main reason states are legitimated in coercing us and we should obey them is that this is the best way for us to help the needy (the needy in general, not just those of our state). In order to achieve this result, states must be territorially defined, that is, they must have power over people living in the same area; but there is nothing in this account that seems able to justify the existence of any special relationship between these people.

For this reason, such a relationship cannot be used by Wellman to justify more robust redistributive duties toward our fellows. In justifying why we have special redistributive duties to them, Wellman cannot make appeal to the very special relationship that he is trying to justify.

\section{The Social Nature of Consumption}

A third consideration that, according to Wellman, can be employed to justify special redistributive responsibilities owed by states to their own citizens is that:

social humans derive satisfaction from their assets . . in relative, rather than objective, terms. That is, since all evaluate themselves in light of their neighbours, each is happy only if she compares favourably to others. ${ }^{49}$

Once this reasoning is applied to individual levels of well-being within the state, it will become clear that:

a person in a less wealthy state will typically derive more satisfaction [from her bundle of resources] than a person in a wealthier state, even though they have the same bundle of resources. ... If this is true, then a poor citizen in a less wealthy state needs fewer resources than a poor citizen in a wealthier state. ${ }^{50}$

48. $I d$.

49. Id. Wellman traces this idea back to Rousseau; see Jean-Jagues Rousseau, The Social Contract (Maurice Cranston, ed. and trans., Penguin Books, 1969) (1762); and Jean-JaQues Rousseau, A Discourse On INeQuality (Maurice Cranston, ed. and trans., Penguin Books, 1984) (1755).

50. Wellman, supra note 40 , at 548 . 
This is certainly an interesting point that warns us about the risks of working with too simplistic conceptions of well-being, but I do not think it will enable Wellman to answer my objection. When I come to decide whether to help Y or Z, I should certainly take into account such considerations in order to have a clear idea of Y's and Z's levels of well-being. By doing so, I will be able to find out who needs my help most, for it might be the case that even if $\mathrm{Y}$ is slightly richer than $\mathrm{Z}$ in absolute terms, I should give my help to $Y$ since the life allowed him by his bundle of resources is worse than that led by $Z$ in a different country. But if it is clear that $Z$ is actually in worse condition than $\mathrm{Y}$, even once we take into account the fact that $\mathrm{Z}$ lives in a less wealthy state, then I should help Z.

The thesis about the social nature of consumption would enable Wellman to answer my objection only if he were ready to claim that the differences existing between the Italian needy and the needy in the Third World will disappear once we consider the average levels of well-being in their respective countries. But this would be quite an odd claim. As a matter of fact, even when we take the social nature of consumption into account, most of the Italian needy who benefit from Italian redistributive policies are still clearly in better condition than people starving in the Third World. Hence the samaritan theory of political obligation should require Italy to employ its resources to assist the latter first. ${ }^{51}$

To see this more clearly, consider the following example. Suppose that Xland is a very rich country. The poorest among the X-ians can afford to have their own houses but not (as most other X-ians) private swimming pools. Suppose that, on the contrary, Y-land is quite a poor country; some Y-landers have decent jobs and posses their own house, but most of them have no job and no house and can hardly make it to the end of the month. Would Wellman claim that if inequalities among X-ians are greater in relative terms than inequalities among Y-landers, the samaritan principle requires X-land to employ its resources to help X-ians rather than Y-landers?

This would strike me as a rather odd conclusion; still, Wellman might be willing to bite the bullet. Notice, however, that Wellman's argument seems to support an even stronger conclusion. According to his argument, in the case that I sketch above, not only should X-land employ its redistributive resources to help X-ians rather than Y-landers, but Y-land should also help $\mathrm{X}$-ians over Y-landers. For if the thesis about the social nature of consumption gives X-land reasons to favor X-ians over Y-landers in its redistributive policies, the same reasons apply to Y-land as well. If it is actually the case that the reason why $\mathrm{X}$-land is justified in favoring $\mathrm{X}$-ians is that inequalities

51. Furthermore, someone might argue that Wellman's considerations about the social nature of consumption should not be taken into account when we are considering urgent needs. The argument here would not be that even considering the social nature of consumption, those starving in the Third World have a stronger claim to Italian redistributive resources than the Italian needy, but rather that these considerations are not relevant in the case of people starving. 
in relative terms among $\mathrm{X}$-ians are more worrisome than inequalities in relative terms among Y-landers, why should this reason not justify Y-land in doing the same ${ }^{52}$

I think that biting the bullet here would be too much; but let us suppose that Wellman were ready to do that. This would not help his position, for the problem with this conclusion is not merely that most people would find it morally repugnant. The main difficulty is that claiming that Y-land should use its resources to help X-ians rather than Y-landers clearly contradicts Wellman's thesis that in their redistributive policies, states should favor their citizens over foreigners.

\section{CAN SAMARITANISM JUSTIFY A MINIMAL STATE?}

Wellman admits that "it is not obvious that a samaritan approach leaves room for a state to redistribute more funds to its own citizens than it does to equally needy foreigners;" 53 but he thinks that this redistributive function can be justified at a second stage by supplementing the samaritan principle with other kind of values, principles, and considerations.

In the previous section I argue that none of the considerations adduced by Wellman in the second stage of his argument can account for those special redistributive responsibilities that states are usually supposed to have towards their own citizens. And I doubt that any consideration able to do that can be found in his account. The problem here is that only associative or transactional accounts of political obligation (i.e., those accounts that ground political obligation respectively in certain roles that we occupy and in certain kinds of interaction $)^{54}$ seem able to generate principles strong enough to account for special redistributive responsibilities to one's compatriots. Weaker considerations, like those proposed by Wellman, will not do the trick because every time that the foreigners' situation is sufficiently worse than one's compatriots', the samaritan principle will trump these considerations and require that help be given to the former rather than the latter.

Moreover, even if we agree with Wellman that we should give priority to eliminating inequalities existing within a society rather than those existing between different societies, this is not enough to conclude that we should give priority to eliminating inequalities within our own society.

Wellman seems not to pay enough attention to the fact that in using Italian redistributive resources to help the needy in the Third World, Italy would be redressing not only those inequalities that exist between Italians and people living in the Third World but also those inequalities that exist between fellow

52. See Christian Coons, Wellman's "Reductive" Justifications for Redistributive Policies That Favor Compatriots, 111 ETHICs 786-788 (2001).

53. See also Wellman, supra note 9 , at 758.

54. For this classification, see Simmons, supra note 8, at 102-103. 
citizens of the states in the Third World. Therefore, if inequalities between fellow citizens of these states are more severe than inequalities existing between Italians, Wellman's argument will justify Italy in giving precedence to the former. Alternately, if inequalities between fellow citizens of states in the Third World and inequalities between Italians are similar, Wellman's argument is not able to justify giving precedence to the latter. ${ }^{55}$

If I am right so far, Wellman could ostensibly try to defend his theory as a justification of only a minimal "night-watcher" state whose functions are limited to solving the coordination problem and ensuring political stability. ${ }^{56}$ Wellman claims that he is ready to do that once it is clear that "our choices are restricted to either settling for the samaritan view, which cannot explain every special political obligation pretheoretically thought to exist, or enduring philosophical anarchism." 57 But is this option really available to him?

I do not think so. If we accept (as Wellman asks us to do) that states can legitimately coerce us insofar as this allows us to discharge our samaritan duties, and if we accept (as I think it is reasonable to do) that some limited redistributive policies would allow us to discharge such duties (by allowing us to rescue people in need at no unreasonable cost), we cannot but conclude that states are justified in coercing us in order to pursue these redistributive policies.

The problem for the samaritan theory is not that it cannot justify redistributive policies but rather that it cannot justify special redistributive policies; that is, it cannot justify a state limiting such policies to (or at least favoring to a great extent) its own citizens over foreigners. So Wellman cannot defend his theory simply by excluding from it the state's redistributive function. What he should do is either reject the idea that these policies should favor the state's own citizens or give us a justification for such limitation.

Consider again my second reformulation of Beth's example, in which Beth has to choose whether to take to the hospital a stranger at risk of death or her daughter, who faces a less serious risk. Some moral theories would probably claim that in such a case Beth is morally justified in giving precedence to her daughter. If so, they should give us a justification for this claim (for example by resting it on the special relationship existing between Beth and her daughter). Alternatively it might be argued that Beth should be impartial and rescue the stranger (this is what some versions of utilitarianism, for example, might claim). What would not be acceptable is a theory that because of its inability to account for the fact that Beth should give precedence to her daughter, would conclude that Beth has no duty to save either of the people in danger. But a move of exactly the same

55. For an objection along these lines, see Coons, supra note 52. See also Peter Singer, One WORLD: THE ETHICS OF GLOBALIZATION 172-175 (2002).

56. Wellman, supra note 9 , at 758 .

57. Wellman, supra note 20 , at 114 . 
kind is involved in Wellman's suggestion that if his theory is unable to justify special redistributive policies, it should be adopted as a defense of a minimal night-watcher state, as if the samaritan duty to perform easy rescues through redistribution of resources could cease to exist just because we do not know how to limit it to benefiting our fellow citizens.

If we accept the samaritan theory, and if we agree that supporting some redistributive policies by the state would not be too costly to count as a samaritan duty, we should conclude that states are justified in coercing us in order to pursue such policies. This conclusion cannot be affected by the fact that the samaritan theory is not able to account for the common intuition that states should favor their own citizens over foreigners. Who should benefit from these policies has nothing to do with these policies being justified according to the samaritan principle.

\section{POSSIBLE CONFLICTS BETWEEN THE SAMARITAN PRINCIPLE AND THE PRINCIPLE OF FAIRNESS}

If the objection that I raise in the previous section works, then Wellman cannot exclude redistributive policies from his theory and adopt the latter as a justification only of a minimal state, for having such policies seems to follow from a coherent application of the samaritan principle. The problem for the samaritan theory, however, is how to account for the widespread idea that those policies should be limited to the state's own citizens. As we see in section $\mathrm{V}$, none of the considerations adduced by Wellman in order to do that seem to work.

What I am interested in considering now is whether Wellman could try to account for this idea by adopting some other kind of consideration. I will argue that he cannot do this either. For the main problem for his theory is not that the samaritan principle might come into conflict with considerations external to the theory, considerations that Wellman might adopt at a second stage of his argument in order to justify states' special redistributive responsibilities. The main problem is that the samaritan principle on some occasions might come into conflict with the principle of fairness, which plays a fundamental role in Wellman's theory, insofar as it enables the theory to justify a duty for every citizen to obey the state.

As we see in section I, it is because of considerations of fairness that I am required to do my part in supporting my state by obeying its laws even when I know that my compliance in particular will make no difference to its capacity to perform its functions. ${ }^{58}$ But what happens when these considerations of fairness come into conflict with the samaritan principle? Consider the following case: I know for sure that if I evade my taxes and send my money to the Third World, I will not threaten the existence of Italy

58. See Section I (Wellman's Theory), pages 197-199. 
as a state ${ }^{59}$ besides, I am pretty sure that by doing so, I would save more people in danger than by paying my taxes (since I know that most of Italy's redistributive resources are employed to help the Italian needy, who are generally in better condition than those in the Third World). Should I obey the law and pay my taxes in this case?

True, if I send my money to the needy in the Third World rather than using it to pay taxes (when most Italians pay their taxes), I would be freeriding on other Italians' compliance with Italian laws, since I would be able to enjoy such a discretion only because other Italians do pay their taxes; but should not my free-riding be accepted by Wellman insofar as it is justified by the samaritan principle, which constitutes the main justification for my duty to obey Italian laws? And should not the same decision be made by other Italians, provided that they are sure that their number is not big enough to put in question Italy's existence as a state? ${ }^{60}$

59. Obviously Italy as a state does not depend for its existence on my contribution. Moreover, suppose that no one knew about my action, so that there would be no risk that my behavior would influence other contributors negatively.

60. Notice that even if my objection here focuses on the case in which by disobeying we can better contribute to meeting the basic needs (other than security) of needy foreigners, my argument in principle also applies to cases in which by disobeying we can better contribute to:

(1) the provision of security (for both compatriots and foreigners);

(2) meeting basic needs other than security of needy compatriots.

If it were possible for me to contribute better to the provision of general security by supporting some institution or some state other than my own, I ought to do so (this would probably have to take the form of a secret disobedience, for I would have to make sure not to put into question the existence of my own state). In the same way, if it were possible for me to contribute better to meeting other basic needs of my fellow citizens by not paying my taxes (and this would not put into question the existence of my own state), I ought to do so. Even if we grant Wellman's view that in both cases I would be acting as a free rider, this should not stop me, for it is the samaritan principle that requires me to do so.

The reason I do not focus on the case in which individuals can contribute better to the provision of security by not obeying their own state is that I tend to agree with Wellman that this kind of situation would be rather unusual. In most cases the best way for me to contribute my fair share to the provision of security for all is by supporting and complying with my own state rather than with any other state or institution.

The reason I do not focus on the case where individuals can better contribute to meeting basic needs other than security of their fellow citizens is that this kind of situation does not pose a problem of principle for the samaritan theory. If I am in a position to help my fellow citizens better by sending my money to some charitable institution rather than by paying my taxes, this means only that my state is inefficient (and possibly, for this reason, unjust to some extent). For all states claim to be concerned with helping those among their citizens who need it the most, and this is the kind of state that Wellman is trying to justify. Of course, the answer to the question whether or not I have a duty to pay my taxes in this case is not straightforward, but this is not a problem for Wellman's theory in particular, because the theory is focused on the duties we have in a just and efficient state. The question of whether we ought to obey a state that is inefficient, and for this reason moderately unjust, is a problem for any theory of political obligation.

Things are different in the case in which individuals can better contribute to meeting basic needs of needy foreigners by not complying with their own state. Since Wellman defends the traditional notion of the state according to which states are justified in giving precedence to their own citizens over needy foreigners, he is committed to claiming that ideally states are 
Wellman might reject this conclusion by recalling the impossibility of establishing what level of noncompliance a state can tolerate (as a matter of fact, this would render the coordination problem much more complicated to solve). However, if this is the only reason to reject such a conclusion, then Wellman's theory would not be able to give a justification for my individual duty to obey the law. Italians would be collectively obligated to obey, but if I were sure that Italy's existence was not at risk and I knew a way to evade taxes, I would have a moral duty to do that and send my money to the Third World rather than support my state by paying them.

To this objection Wellman might answer that fairness is not "merely added to samaritanism" but rather "necessary for samaritanism to obtain" in the context of political obligation. ${ }^{61}$ But in what sense is it necessary? Fairness can be said to be "necessary for samaritanism to obtain" if by refusing to do my part I put into question the existence of the state and hence its capacity to rescue others from the perils of the state of nature. But once the existence of the state is out of doubt and I know for sure that my disobedience will not make any difference, it seems that fairness is no longer necessary for samaritanism to obtain. It would be only for reasons of fairness that I would be required to do my part, but this, as I argue above, could turn out to be in conflict with what is required by samaritanism.

What options are available to Wellman at this point? He could answer the objection raised by my example in two ways. The first option is to claim that in the case that I present above, I do not have any duty to support my state by paying my taxes but I should rather discharge my samaritan duty by sending my money to the Third World. Notice that this would be to claim that for each citizen the duty to obey the law is conditional on her obedience being necessary for the existence of the state. So those citizens whose disobedience would not put the existence of the state in jeopardy would not have a duty to obey the law. This would be a peculiar conception of the duty to obey the state: a duty that is valid only for some citizens and on some occasions. What Wellman is trying to justify is rather the traditional duty to obey the state: a duty that, even if prima facie, is always valid for every citizen.

Alternatively, Wellman can claim that I have a duty to pay my taxes even when I know that by evading them and sending my money to the Third World, I would save a larger number of people in danger, and even if I am sure that this would not make any difference to the existence of Italy as a state: when samaritanism and fairness come into conflict with each other, the latter should trump the former. But notice that in that case, what justifies my obedience would not be samaritanism but rather fairness. If this

justified in helping certain groups of individuals (their citizens), even when they need it less than other individuals (foreign needy). This is not the unwelcome outcome of some mistaken policy adopted by states in the nonideal world but, rather, an implication of Wellman's own ideal theory which is in startling conflict with the samaritan principle.

61. Wellman, supra note 10, at 237. 
were Wellman's answer, he would be abandoning the samaritan theory and adopting a fair-play theory of political obligation. ${ }^{62}$

\section{CONCLUSION}

I began by presenting an outline of Wellman's theory of state legitimacy and political obligation. The main ground of the theory is a natural duty to help people in need when this can be done without unreasonable cost. But this samaritan principle needs to be supplemented first by a principle of fairness, in order to justify the duty to obey the law for every citizen, and then by three further considerations (about the importance of effective rights, about relational equality, and about the social nature of consumption), in order to justify states' special redistributive responsibilities toward their own citizens.

My first argument against Wellman's theory was that it could not justify these special redistributive responsibilities. Even granting that the samaritan theory can offer a justification both of Italy being legitimated in coercing Italians and of Italians' duty to obey Italian laws, it is not able to justify the view that in its redistributive policies, Italy should be more concerned about the Italian needy rather than the needy in the Third World. I defended this conclusion by arguing that helping foreigners is not necessarily more costly than helping compatriots; then I strengthened my case by arguing that the samaritan theory would require Italy to help the needy in the Third World (rather than Italians) even if helping them were more costly, provided that it were not too costly. ${ }^{63}$

I explained why Wellman's three considerations about the importance of effective rights, about relational equality, and about the social nature of consumption do not enable his theory to answer my objection. The point is that every time the foreigners' situation is sufficiently worse than our compatriots', the samaritan principle will trump these considerations and require us to help foreigners rather than compatriots. Moreover, Wellman's argument that we should give priority to eliminating inequalities that exist within a society rather than those existing between different societies does not imply that we should give priority to eliminating inequalities within our own society.

Finally, after rejecting the possibility of adopting the samaritan theory as a justification of a minimal "night-watcher" state, I considered the problem of possible conflicts between the samaritan principle and the principle of fairness. A clear case is when I know that by evading my taxes and sending my money to the Third World, I would save more people in danger than

62. Here it is worth noting that Wellman explicitly rejects those theories that ground political obligation in the principle of fairness. See Wellman, supra note 9, at 737-738.

63. I also argued that in a coherent formulation of the theory, helping them is never going to be too costly. 
by paying my taxes and I also know for sure that this will not threaten the existence of Italy as a state.

In this case Wellman cannot claim that fairness should trump samaritanism without abandoning his theory, so he has only two options available. He can argue that not every citizen has a duty to obey the law, because this duty is conditional on a particular act of obedience being essential to preserve the existence of the state. Alternatively, he can argue that every citizen has a duty to obey the law, but that in their redistributive policies states should not be more concerned about their citizens than about foreigners. ${ }^{64}$

As I have said, the first of these strategies is not compatible with the notion of political obligation that Wellman would like to justify (the notion of a prima facie duty always valid for every citizen), while the second is not compatible with the current view of the relationships that should exist between states, citizens, and foreigners (according to which states should have special redistributive concerns for their own citizens). So the only way not to reject Wellman's theory is either to give up the traditional notion of political obligation ${ }^{65}$ or to change this last view and claim that there is no moral justification for states favoring their citizens over foreigners.

64. A third possible option available to Wellman would be to claim that every citizen has a duty to obey the law but that the content of laws about taxes is conditional. These laws would require me to pay taxes only if there is no other, better way for me to discharge my samaritan duty. So, for example, in the case that I am considering, they would require me to send my money to the Third World. But notice that this solution (besides being quite odd) would involve again giving up both the idea of special concerns for our compatriots and the idea of states' special redistributive responsibilities to their citizens.

65. See, e.g., Joseph Raz, The Morality of Freedom 99-105 (1986); and Green, supra note 9, at 228-230, 240-247. 